\title{
Evaluation of Antioxidant Capacity and Antiproliferative Activity of Fruit Extract of Dry Figs (Ficus carica L.) on MDA MB-468 Cell Line
}

\section{Anurag Maurya}

University of Delhi

\section{Eepsita Priyadarshini}

Jawaharlal Nehru University

Paulraj Rajamani ( $\square$ paulrajr@mail.jnu.ac.in )

Jawaharlal Nehru University https://orcid.org/0000-0003-4922-9028

\section{Research Article}

Keywords: Ficus carica L. (fig), antioxidant capacity, phenolic compounds, UPLC-PDA, antiproliferative activity, MDA MB-468 cells

Posted Date: December 28th, 2021

DOI: https://doi.org/10.21203/rs.3.rs-1145771/v1

License: (c) (i) This work is licensed under a Creative Commons Attribution 4.0 International License. Read Full License 


\section{Abstract}

Fig (Ficus carica L.; Hindi: Anjeer) is one of the the earliest domesticated fruit. Present study investigates its antiproliferative activity against breast cancer (MDA MB-468) cells. Dry figs were mascerated in sixteen solvent-combinations of varying polartiy and extracts were assessed for antiproliferative activity in vitro. Extracts of moderatly polar solvents, particularly $80 \%$ aqueous-methanol extract showed maximum activity $\left(\mathrm{IC}_{50}=17.9 \mathrm{mg} \mathrm{IDF} / \mathrm{ml}\right)$. Antiproliferative efficacy of extracts was supported by respective total phenolic content (41-236 mg GAE/100g) and various antioxidant capacities; ABTS (14-354 $\mu \mathrm{M} \mathrm{TE/g),} \mathrm{DPPH} \mathrm{(18-460}$ $\mu \mathrm{M} \mathrm{TE} / \mathrm{g}), \operatorname{FRAP}\left(28.7-66.5 \mu \mathrm{M} \mathrm{FeSO}_{4}\right.$ equivalents/g), ORAC (7.9-32.8 $\left.\mu \mathrm{M} \mathrm{TE} / \mathrm{g}\right)$, and superoxide radical scavenging activity. Flow cytometry analysis revealed that extracts of lower $\mathrm{IC}_{50}$ induce more cell death. Phenolic compounds (cyanidin 3-0-glucoside, quercetin 3- $\beta$-glucoside, rutin, trans-cinnamic acid, ellagic acid and ferulic acid) were analysed by UPLC-PDA technique and their concentrations in extracts were found to be negatively correlated with respective $\mathrm{IC}_{50}$ values. The negative correlation suggests the involvement of phenolics in fig's antiproliferative mechanism. Therefore, the study advocates fig as a dietary component having anticancer potential.

\section{Introduction}

Breast cancer is the most recurrent cancer among women with approximately 1.7 million diagnosis per year over the globe. It claimed 522,000 lives of the world's women population in the year, 2012 (Ginsburg et al., 2017). Breast cancer become leading cancer ahead of cervical cancer in Indian women with 144937 new registered cases and 70218 deaths (Asiaf, Ahmad, Malik, \& Aziz, 2015). Nevertheless, survival rate of breast cancer patients increased in recent years due to diagnostic and therapeutic interventions but effective curative method is still an inevitable necessity (Li et al., 2013).

Epidemiological studies found an inverse correlation of fruit and vegetable consumption with the risk of cancer in various organs including that of breast (Farvid et al., 2016). Addition of fruit and vegetables in diet with intention to minimise cancer risk is called dietary chemoprevention. Non-nutrient components of fruits and vegitables, called phytochemicals, such as alkaloids, polyphenols, and phytosterols etc. are considered the major active components of medicinal value. Many phytochemicals which target cancer cells are antioxidant in nature as they reduce cellular reactive oxygen species (ROS) level. High ROS level accompanies carcinogenesis and is essential for cancer cell homeostasis. Therefore, antioxidant rich fruits and vegetables have been frequently explored for their anticancer activity (Russo, 2007) and several research are still ongoing.

Fig (Ficus carica L.) is an antioxidant rich fruit. It is a frutescence- a group of druplets enclosed in a leathery receptacle, called syconium. Fig is considered to be one of the first domesticated fruit tree. Although, fig is native to Mediterranean countries but it is cultivated in some parts of India also, mostly in and adjoining areas of Pune and Aurangabad (Maharastra). Common Indian varieties are Conadria, Excel, Deanna, Poona and Dinkar (Gawade \& Waskar, 2005). People consume cream, jam and jelly, etc. as the proceeseed form of fig; however, raw fruit is more popular, eaten fresh or dried. Since, fresh fig is highly perishable with shelf life of 7-10 days at low-temperature storage; hence dry fruit is comparatively more popular (Lim, 2012). 
Earlier studies reported high quantitiy of phenolics in fig. Important phnolics are cyanidin 3-rutinoside and cyanidin 3-O-glucoside, Quercetin 3-0-rutinoside, 3-0-caffeoylquinic acid, 5-0-caffeoylquinic acid, ferulic acid, and quercetin 3-ß-glucoside (Barolo, Ruiz Mostacero, \& López, 2014; Lim, 2012). On the basis of phenolic composition and its antioxidant propertry, fig is investigated for its anticancer property. Although, milky latex extracted from leaves and twigs of the plant had been studied thoroughly; but riped fruits of fig, the edible part, remain comparatively underexplored for its anticancer potential. Marrelli et al., (2012) reported photodynamic cytotoxicity of hydroalcoholic extract of fig with ultravilote light in in vitro.

Therefore, in the present study we aimed at exploring the antiproliferative activity of fig extracts $\backslash$ against triple negative breast cancer (MDA MB-468) cells and to find out its correlation with respective total phenolic content (TPC) and antioxidant capacity of various solvent extract of fig. Comparative analysis of fig extracts in different solvents with varying polarity was performed to determine the maximum TPC content and antiploriferative analysis. Moreover, UPLC analysis of the extracts was also conducted to elucidate the phenolic constitutes of fig fruit.

\section{Materials And Methods 2.1. Materials}

Gallic acid, 2,2-diphenyl-1-picrylhydrazyl (DPPH), 2,2'-azino-bis(3- ethylbenzothiazoline-6-sulfonic acid) diammonium salt (ABTS), 2,4,6-tri(2-pyridyl)-s-triazine (TPTZ), nitrotetrazolium blue chloride (NBT), ( \pm )-6hydroxy-2,5,7,8-tetramethyl-chromane-2-carboxylic acid (trolox), fluorescein, 2,2'-azobis(2-

methylpropionamidine) dihydrochloride (AAPH), rutin, quercetin 3- $\beta$-glucoside, ellagic acid, ferulic acid, cyanidin 3-O-glucoside, trans-cinnamic acid and thiazolyl blue tetrazolium bromide (MTT) were purchased from Sigma-Aldrich, SL, USA. All solvents used in the study were of HPLC grade and purchased from Merck Pvt Ltd, India. Dulbecco's modified eagle medium (DMEM), antibiotic-antimycotic, trypsin, fetal bovine serum was procured from Invitrogen, India Pvt Ltd. Polymeric C18-silica cartridge (BOND Elut C18) was procured from Agilent Technologies. Dry fig was purchased froma local grocery shop, New Delh, India.

\subsection{Fig extract preparation and yield}

Acetone, ethanol, methanol and DMF, commonly employed solvents for extraction of plant phenolics (Turkmen, Sari, \& Velioglu 2006), were used for extraction purpose. The required solvent concentartion was prepared by adding appropriate volume of MilliQ water. Four absolute solvents (100\%) and their mixtures ( $80 \%$ and $50 \%$ ), a total of 12 different combinations, were used in extraction process by maceration method.

In brief, four grams of small pieces of dry fig was macerated in $25 \mathrm{ml}$ of each of the 12 different extraction solvents at room temperature (RT) for 15 days in the dark. Thereafter, the solvent extracts were filtered through membrane filter $(0.22 \mu \mathrm{M})$ and lyophilised. Yield of each of the solvent extract was determined by weighing the dried residue and then dissolved in $4 \mathrm{ml}$ MilliQ water. Concentration of dissolved residue is represented as, 'Infusion from 1 gram of Dry Fig per ml (1g IDF/ml)'. Extracts ( $1 \mathrm{~g}$ IDF/ml) were diluted aptly and employed for determination of total phenolic content, antioxidant capacity and antiproliferative activity. 


\subsection{Determination of total phenolic content (TPC)}

TPC was determined by the Folin-Ciocalteu method (Bachir Bey, Meziant, Benchikh, \& Louaileche, 2014) with minor modifications. In brief, $100 \mu$ l extract sample, gallic acid standard (50 to $750 \mathrm{mg} / \mathrm{ml}$ ), or blank (water) was added to $200 \mu \mathrm{l}$ of $10 \%$ ( $\mathrm{vol} / \mathrm{vol}$ ) Folin-Ciocalteu reagent. After 5 min of incubation in dark at RT, $800 \mu \mathrm{l}$ sodium bicarbonate $(700 \mathrm{mM})$ solution was added. Solution mixture was incubated in dark for $5 \mathrm{~h}$ and absorbance was mesured at $765 \mathrm{~nm}$ using spectrophotometer (Shimadzu UV-1800). Phenolic content of the sample was calculated from gallic acid standard curve and represented as milligram of gallic acid equivalent per 100 gram of fruit (mg GAE/100g).

\subsection{Antioxidant assays}

\subsubsection{DPPH assay}

DPPH assay was performed following the method described elsewhere (Slatnar, Klancar, Stampar, \& Veberic, 2011 ) with slight modification. Briefly, $200 \mu \mathrm{l}$ of sample, trolox standard (50 to $800 \mu \mathrm{M}$ ) or blank (water) was mixed with $3000 \mu \mathrm{l}$ of fresh working solution $(0.025 \mathrm{mM})$ of DPPH. After $5 \mathrm{~h}$ incubation in dark at RT, decolourisation of DPPH was measured at $515 \mathrm{~nm}$ using the spectrophotometer (Shimadzu UV-1800). The extent of decolourisation was determined using trolox standard and expressed as micromole trolox equivalent per gram of fruit $(\mu \mathrm{M} \mathrm{TE} / \mathrm{g})$.

\subsubsection{ABTS assay}

ABTS assay was performed according to the method followed by Thaipong, Boonprakob, Crosby, CisnerosZevallos \& Byrne (2006) with minor alterations. Briefly, $200 \mu$ l of sample, blank (water), or trolox standard (50 to $800 \mu \mathrm{M}$ ) was added to working ABTS ${ }^{\circ}$ radical solution $(3000 \mu \mathrm{l})$ and incubated for $5 \mathrm{~h}$ in dark at RT. Decolourisation was measured at $734 \mathrm{~nm}$ using spectrophotometer (Shimadzu UV-1800). Antioxidant capacity of sample was calculated from trolox standard curve and expressed as $\mu \mathrm{M} \mathrm{TE} / \mathrm{g}$.

\subsubsection{FRAP assay}

Method described by Thaipong et al. (2006) was followed for FRAP (ferric reducing antioxidant power) assay with minor changes. Briefly, TPTZ (10 mM) solution was prepared in $40 \mathrm{mM}$ hydrochloric acid. TPTZ $(10 \mathrm{mM}, 2.5 \mathrm{ml})$ and $\mathrm{FeCl}_{3}(20 \mathrm{mM}, 2.5 \mathrm{ml})$ was added to $25 \mathrm{ml}$ of acetate buffer $(300 \mathrm{mM}, \mathrm{pH} 3.6)$ and warmed $\left(37^{\circ} \mathrm{C}, 15 \mathrm{~min}\right)$ for formation of straw coloured FRAP reagent ( $\mathrm{Fe}^{3+}-\mathrm{TPTZ}$ complex). Thereafter, 200 $\mu \mathrm{l}$ of sample, blank (water), or $\mathrm{FeSO}_{4}$ standard $(0.2$ to $0.8 \mathrm{mM}$ ) was added to $3000 \mu$ l of prewarmed FRAP reagent. The solution was incubated for $5 \mathrm{~h}$ in dark at RT. Intensity of developed blue colour was measured at $593 \mathrm{~nm}$ with aid of spectrophotometer (Shimadzu UV-1800). Ferric reducing ability of samples was 
calculated from $\mathrm{FeSO}_{4}$ standard curve and denoted as micromole equivalents of $\mathrm{FeSO}_{4}$ per gram fruit ( $\mu \mathrm{M}$ $\mathrm{FeSO}_{4} \mathrm{E} / \mathrm{g}$ ).

\subsubsection{ORAC assay}

ORAC (oxygen radical antioxidant capactiy) assay was performed according to the protocol described earlier (Reddy, Sreeramulu, \& Raghunath, 2010) with some modification. Twenty microliter of extract sample, blank, or trolox standard (50 to $800 \mu \mathrm{M}$ ) was mixed with $2000 \mu \mathrm{l}$ of fluorescein (40 nM) solution. To the preheated mixture at $37^{\circ} \mathrm{C}, \mathrm{AAPH}(200 \mu \mathrm{l})$ was added to initiate fluorescein decomposition. The curve of decline in fluorescence intensity with respect to time was recorded in spectrofluorometer (Shimadzu RF5301PC). The area under curve (AUC) was calculated for each sample and standard. Trolox standard curve was prepared based on the AUC at respective trolox concentration and respective AUC. ORAC of samples were calculated from trolox snatdard curve and expressed as $\mu \mathrm{M} \mathrm{TE} / \mathrm{g}$.

\subsubsection{Superoxide radical scavenging activity (SRSA)}

Superoxide radical scavenging activity (SRSA) was assessed by the method adopted by Govindan \& Muthukrishnan (2013) with minor modification. Reaction mixture $(1 \mathrm{ml})$ of riboflavin $\left(1.33 \times 10^{-5} \mathrm{M}\right)$, methionine $\left(4.46 \times 10^{-5} \mathrm{M}\right)$, NBT $\left(8.15 \times 10^{-8} \mathrm{M}\right)$ and the sample was prepared in $0.05 \mathrm{M}$ phosphate buffer $(\mathrm{pH} 7.8)$. The reaction mixture was illuminated with fluorescent lamps $(40 \mathrm{~W})$ at $25^{\circ} \mathrm{C}$ for $40 \mathrm{~min}$. The nonilluminated reaction mixture was used as blank. The absorbance was measured at $560 \mathrm{~nm}$. Percent inhibition of blue colour development was calculated.

\subsection{Sample cleanup (solid-phase extraction) and UPLC-PDA analysis}

Polymeric C18-silica cartridge (BOND Elut C18, Agilent Technologies) was used for the sample cleanup (solid-phase extraction). Cartridge was conditioned with $10 \mathrm{ml}$ ethyl acetate, $10 \mathrm{ml}$ absolute methanol, and $10 \mathrm{ml}$ acidified water ( $0.01 \mathrm{~N}$ aqueous hydrochloric acid) sequentially. Five hundred microlitre of sample $(1 \mathrm{~g}$ $\mathrm{IDF} / \mathrm{ml}$ ) was loaded on conditioned cartridge. Loaded cartridge was washed with $10 \mathrm{ml}$ acidified water, dried under nitrogen stream and eluted with $40 \mathrm{ml}$ ethyl acetate for phenolics. Solvent from the elute was evaporated and residue was reconstituted in $500 \mu \mathrm{l}$ methanol which was used for UPLC-PDA analysis (Kim \& Lee, 2005).

The chromatographic separation was performed using Acquity UPLC-PDA system (Waters Pvt Ltd). A binary gradient consisting of solvent $A$ ( $0.1 \%$ trifluoroacetic acid (TFA) in water), and B ( $0.1 \%$ TFA in acetonitrile) with flow rate of $0.2 \mathrm{ml} / \mathrm{min}$ through UPLC BEH-C18 analytical column $(2.1 \mathrm{~mm} \times 150 \mathrm{~mm} ; 1.7 \mu \mathrm{m}$, Waters, USA) at $30{ }^{\circ} \mathrm{C}$. The injection volume was $5 \mu \mathrm{L}$. Gradient of solvent A was: initial $95 \%, 0-1 \mathrm{~min} 75 \%, 1-2 \mathrm{~min}$ $56 \%$, 2-3 min 54\%, 3-4 min 52\%, 4-5 min 50\%, 5-6 min 48\%, 6-7 min 46\%, 7-8 min 44\%, 8-9 min 42\%, 9-10 min $40 \%, 10-10.5 \mathrm{~min} 25 \%$, and $10.5-11 \mathrm{~min} 0 \%$. Retention time of individual standard was used for 
indentification of overlapping peak in sample. Calibaration curve was prepared from peak areas of different concentration of each standard, and the corresponding peak in the sample was quantified.

\subsection{Cell culture}

Triple negative human breast cancer (MDA MB-468) cell line was procured from National Centre for Cell Sciences, Pune, India. Monolayer culture of the cell was maintained in Dulbecco's modified Eagle's medium (DMEM) supplemented with $10 \%$ fetal bovine serum, $1 \%$ antibiotic-antimycotic with incubation in a humidified incubator maintained at $37^{\circ} \mathrm{C}, 5 \%$ carbon dioxide and $95 \%$ atmospheric air.

\subsection{MTT assay}

Antiproliferative property of fig extracts were determined by MTT assay (Kumar et al., 2012). Cells were seeded in 96 well plates ( $1 \times 10^{4}$ cells/well) and treated with 10, 20,30, 40 and $50 \mathrm{mg}$ IDF/ml of each of the extract in separate wells. After $24 \mathrm{~h}$ of treatment, cells were incubated with $20 \mu \mathrm{l}(5 \mathrm{mg} / \mathrm{ml})$ of MTT at $37^{\circ} \mathrm{C}$ for $4 \mathrm{~h}$. Formazan crystals were dissolved in $200 \mu \mathrm{l}$ of dimethyl sulfoxide (DMSO) and absorbance was recorded at $570 \mathrm{~nm}$ using microplate reader (BioRad iMark). Percent cell viability was calculated and presented as mean \pm standard error of mean (SEM).

\subsection{Flow cytometry}

Flow cytometry was performed to evaluate cell death after treatment by adapting method of Riccardi \& Nicoletti (2006) with some modification. Briefly, cells were seeded in 12 well p;ate $\left(2 \times 10^{5}\right.$ cells/well $)$ and treated with medium containing 20 and $40 \mathrm{mg} \mathrm{IDF} / \mathrm{ml}$ of each solvent extract for $24 \mathrm{~h}$. Floating as well as adherent cells were harvested, washed with phosphate buffered saline (PBS, pH 7.4) and fixed using chilled $70 \%$ methanol. Fixed cells were rehydrated and washed with PBS, incubated for 5 min in DNA extraction buffer. Cells were mixed in propidium iodide staining buffer having DNase free RNase-A and incubated at $37^{\circ} \mathrm{C}$ in dark for $2 \mathrm{~h}$. Dead and live cells were scored by flow cytometry (BD FACSVerse flow cytometer equipped with FACsuite software) and red fluorescence acquired.

\subsection{Statistical Analysis}

Statistical analyses of data were performed using Graphpad Prism and Microsoft office excel software and presented as mean \pm standard error of mean (SEM). One-way analysis of variance (ANOVA) was applied for multiple comparison of test groups. For phytochemical analyses, Tukey's tests was applied to compare each group with rest of other groups. Each of the treated group was compared with control group employing Dunnett's test for MTT assay. Median inhibitory concentrations $\left(\mathrm{IC}_{50}\right)$ values were calculated by regression analysis. Pearson's Correlation coefficients were computed for correlation studies. 


\section{Result And Discussion \\ 3.1. Extraction yield}

After maceration of Fig in twelve distinct combinations of solvents, each infusion/extract was dried and yield calculated. Extraction yields for $100 \%, 80 \%$, and $50 \%$ of acetone, ethanol, methanol and DMF extracts were determined to be $35.76 \pm 1.0^{\mathrm{b}}, 160.76 \pm 13.3^{\mathrm{a}}, 165.66 \pm 15.5^{\mathrm{a}}, 44.43 \pm 1.8^{\mathrm{b}}, 153.66 \pm 12.8^{\mathrm{a}}, 154.63 \pm$ $12.7^{\mathrm{a}}, 163.10 \pm 4.3^{\mathrm{a}}, 165.73 \pm 6.1^{\mathrm{a}}, 152.05 \pm 10.7^{\mathrm{a}}, 184.16 \pm 10.7^{\mathrm{a}}, 166.36 \pm 3.4^{\mathrm{a}}, 162.46 \pm 6.3^{\mathrm{a}} \mathrm{mg} / \mathrm{g}$ respectively. The values (mean $\pm S E M)$ superscripted with different alphabets are significantly different $(P<$ $0.05)$ from each other. These values demonstrated that solvents of the lowest polarity that is absolute acetone $(35.76 \pm 1.0 \mathrm{mg} / \mathrm{g})$ and absolute ethanol $(44.43 \pm 1.8 \mathrm{mg} / \mathrm{g})$ had significantly $(P<0.05)$ lower yield compared to the other ten solvents of high polarity. Though the differences were not statistically significant, yet observations indicates that addition of water in less polar solvents (acetone and ethanol) increased the yield, but additional water decreased the yield for high polarity solvents (methanol and DMF). It was thus infered that medium polar combination of solvents were optimum for extraction yield, which is in agreement with earlier reports. Polar compounds such as carbohydrate, organic acids, and protein increase the yield with increasing fraction of water in solvents (Turkmen et al., 2006; Do et al., 2014).

\subsection{Total phenolic content (TPC)}

TPC of various solvent extracts (Fig. 1) ranged from $67.03 \pm 0.9$ to $220.9 \pm 12.59 \mathrm{mg} \mathrm{GAE} / 100 \mathrm{~g}$. Nearly three to four-fold higher TPC was observed as compared to those reported earlier on fresh figs (Kamiloglu \& Capanoglu, 2014; Slatnar et al., 2011). The TPC in fig is comparatively higher than many other fruits like pear, orange, lemon, peach, banana, pineapple, strawberry, red grape and vegetables such as cucumber, celery, lettuce, potato, cabbage, carrot, red pepper, onion, spinach and broccoli (Chu, Sun, Wu, \& Liu, 2002; Sun, Chu, Wu, \& Liu, 2002).

TPC was highest in $100 \%$ DMF extract followed by $50 \%$ acetone, $80 \%$ DMF, and $80 \%$ methanol extract sequentially. Solvents of intermediate TPC yield as followes: $100 \%$ methanol > 50\% DMF > 50\% ethanol > $80 \%$ acetone $>80 \%$ ethanol $>50 \%$ methanol. TPC was least in absolute acetone and slightly higher in absolute ethanol (Fig. 1). The trend demonstrates an equivalent increase in TPC with increasing polarity/fraction of water for less polar organic solvents i.e. ethanol $(100 \%<80 \%<50 \%)$ and acetone $(100 \%$ $<80 \%<50 \%$ ). In case of methanol, $50 \%$ methanol extract showed highest TPC followed by $80 \%$ methanol and least in absolute methanol. Addition of water in absolute DMF was reducing the TPC yield as it was decreasing in the order: $100 \%>80 \%>50 \%$ (Fig. 1). Thus, the nature of solvent and content of water in the solvent affected TPC yield. Medium polar combination of solvents was found appropriate for TPC recovery. These observations were in accordance with previous reports and suggested an optimum TPC recovery by solvent combinations of medium polarity (Bachir Bey et al., 2014; Turkmen et al., 2006).

Moreover, TPC result shows that binary hydro-organic solvent is better for TPC recovery as compared to mono-component solvent system. Increasing fraction of water alters density, viscosity and dielectric 
constant of solvents. Solvation of hydrophilic matrix by water loosens cell wall matrix, hence facilitating penetration of extraction solvent, and enabling better mass transfer of the compounds. Organic solvent makes hydrophobic interaction weaker and solubilises phenolics and other phytochemicals. Conversely, addition of water increases the polarity of solvent mixture, reducing the solubility of relatively hydrophobic phenolics (Boeing et al., 2014).

\subsection{Antioxidant assays}

Methods for antioxidant capacity measurement can be broadly categorised as hydrogen atom transfer (HAT) based assays and electron transfer (ET) based assays. ORAC is an example of HAT-based assay in which antioxidant molecule act as hydrogen donor. ET-based assays (for example DPPH, ABTS, FRAP and TPC by Folin-Ciocalteu method) are based on the degree of colour change of respective synthetic oxidants after receiving electron from antioxidants (Prior, Wu, \& Schaich, 2005).

Total antioxidant capacity (TAOC) was quantified by DPPH and ABTS assay. In both the assays antioxidant activity of various extracts followed a similar trend (Table 1). It was highest in $100 \%$ DMF, followed by $80 \%$ DMF, 50\% acetone and $80 \%$ methanol extract. On the other hand, it was the least in $100 \%$ acetone and slightly high in $100 \%$ ethanol extract. Other extracts had intermediate antioxidant capacity in decreasing sequence; $100 \%$ methanol $>50 \%$ DMF $>80 \%$ acetone $>50 \%$ ethanol $>50 \%$ methanol $>80 \%$ ethanol. It is thus infered that as the polarity of the three solvents (acetone, ethanol, and methanol) enhanced with increasing proportion of water, their antioxidant capacity also increased, except $50 \%$ methanol extract, which has lower antioxidant capacity than $80 \%$ methanol extract. Any additional water in DMF result in decrease of antioxidant capacity of the extracts. Medium polarity of solvents favoured antioxidant's recovery. Previous studies also reported that moderately polar solvents yield a high antioxidant capacity (Bachir Bey et al., 2014; Turkmen et al., 2006).

ABTS and DPPH antioxidant capicities of extracts show strong positive correlation $(r=0.926)$ (Table 2). ET based mechanism of action in both the assays might be the reason for the strong correlation. A strong correlation of TPC with DPPH $(r=0.808)$ and ABTS $(r=0.889)$ antioxidant capcities demonstrated that phenolics may be major antioxidants present in fig extract (Slatnar et al., 2011).

In FRAP assay, antioxidants donate an electron to TPTZ- $\mathrm{Fe}^{3+}$ complex and reduce it to TPTZ-Fe ${ }^{2+}$. High level of FRAP activity was found in fig ranging from 28 to $73 \mu \mathrm{M} \mathrm{FeSO}_{4}$ equivalents $/ \mathrm{g}\left(\mu \mathrm{M} \mathrm{FeSO} \mathrm{F}_{4} \mathrm{E} / \mathrm{g}\right)$ (Table 1) in various solvent extracts. FRAP values were comparable to that of common dry fruits of Indian diet i.e. almond, apricot, brown raisins,

\section{Table 1. Antioxidant capacities and $I_{50}$ values of dry fig extracted in different solvents}




\begin{tabular}{|c|c|c|c|c|c|c|}
\hline Solvent & $\begin{array}{l}\text { ABTS } \\
\text { assay a }\end{array}$ & $\begin{array}{l}\text { DPPH assay } \\
\text { a }\end{array}$ & FRAP assay ${ }^{\beta}$ & ORAC $^{a}$ & $\%$ SRSA $^{Y}$ & $\mathrm{IC}_{50}{ }^{\delta}$ \\
\hline \multicolumn{7}{|l|}{ Acetone } \\
\hline $100 \%$ & $13.9 \pm 0.8^{c}$ & $18.1 \pm 1.0^{d}$ & $28.68 \pm 6.6^{\text {def }}$ & $78.7 \pm 18^{d}$ & $32.3 \pm 1.1$ & $80.4 \pm 6.8$ \\
\hline $80 \%$ & $217.4 \pm 7.2^{\mathrm{ab}}$ & $282.6 \pm 9.3^{\mathrm{ac}}$ & $53.03 \pm 1.7^{\mathrm{abcf}}$ & $182.7 \pm 16^{\mathrm{cd}}$ & $51.6 \pm 3.1^{\mathrm{bd}}$ & $41.2 \pm 3.4$ \\
\hline $50 \%$ & $263.3 \pm 1.5^{\mathrm{ad}}$ & $342.3 \pm 1.9^{a}$ & $63.70 \pm 5.1^{\mathrm{ab}}$ & $267.9 \pm 19^{a b}$ & $62.7 \pm 0.3^{d}$ & $36.4 \pm 2.4$ \\
\hline \multicolumn{7}{|l|}{ Ethanol } \\
\hline $100 \%$ & $44.1 \pm 1.4^{c}$ & $57.3 \pm 1.8^{\mathrm{d}}$ & $28.31 \pm 6.2^{\mathrm{de}}$ & $89.1 \pm 23^{d}$ & $42.0 \pm 0.8^{\mathrm{ca}}$ & $43.3 \pm 2.2$ \\
\hline $80 \%$ & $141.5 \pm 12.8^{b}$ & $183.9 \pm 16.6^{c}$ & $55.23 \pm 6.9^{\mathrm{abcd}}$ & $192.2 \pm 18^{\mathrm{cd}}$ & $48.5 \pm 0.3^{\mathrm{ab}}$ & $38.1 \pm 2.3$ \\
\hline $50 \%$ & $185.7 \pm 24.4^{\mathrm{bd}}$ & $241.2 \pm 31.7^{c}$ & $62.26 \pm 9.0^{\mathrm{abc}}$ & $227.0 \pm 23^{a}$ & $47.6 \pm 1.6^{d}$ & $30.3 \pm 1.3$ \\
\hline \multicolumn{7}{|c|}{ Methanol } \\
\hline $100 \%$ & $251.1 \pm 8.3^{\mathrm{a}}$ & $326.4 \pm 10.8^{a}$ & $57.05 \pm 1.4^{\mathrm{a}}$ & $280.2 \pm 36^{a}$ & $45.7 \pm 1.6^{\mathrm{a}}$ & $36.8 \pm 3.2$ \\
\hline $80 \%$ & $259.5 \pm 15.2^{\mathrm{a}}$ & $337.4 \pm 19.8^{\mathrm{ab}}$ & $62.52 \pm 5.9^{\mathrm{ab}}$ & $250.3 \pm 28^{\mathrm{ab}}$ & $68.4 \pm 0.4$ & $17.9 \pm 1.2$ \\
\hline $50 \%$ & $183.2 \pm 0.7^{b}$ & $238.1 \pm 1.0^{c}$ & $42.50 \pm 2.3^{\mathrm{ac}}$ & $159.5 \pm 14^{\mathrm{bc}}$ & $51.5 \pm 0.1^{b}$ & $38.3 \pm 3.2$ \\
\hline \multicolumn{7}{|l|}{ DMF } \\
\hline $100 \%$ & $353.7 \pm 11.5$ & $459.9 \pm 15.0^{\mathrm{a}}$ & $73.74 \pm 4.5^{\mathrm{ab}}$ & $328.6 \pm 43^{a}$ & $50.6 \pm 0.6^{\mathrm{ab}}$ & $22.0 \pm 3.3$ \\
\hline $80 \%$ & $264.1 \pm 11.2^{\mathrm{ab}}$ & $343.4 \pm 14.6^{\mathrm{ab}}$ & $66.52 \pm 3.4^{\mathrm{abf}}$ & $276.7 \pm 25^{\text {ade }}$ & $45.6 \pm 0.5^{\mathrm{ac}}$ & $30.1 \pm 2.2$ \\
\hline $50 \%$ & $230.7 \pm 2.1^{\mathrm{a}}$ & $299.9 \pm 3.0^{\mathrm{bc}}$ & $41.85 \pm 6.1^{\mathrm{ec}}$ & $156.4 \pm 17^{e}$ & $38.9 \pm 0.6^{c}$ & $62.3 \pm 3.4$ \\
\hline Range & $14-354$ & $18-460$ & $28.7-66.5$ & $79-328$ & $32-68$ & $17.9-80.4$ \\
\hline \multicolumn{7}{|c|}{$\begin{array}{l}\text { Note: Values are given as mean } \pm \text { SEM }(n=9) \text {; values with different letters are significantly different } \\
\text { from each other }(p<0.05)\end{array}$} \\
\hline \multicolumn{7}{|c|}{${ }^{\beta}$ values are expressed as micromole of $\mathrm{FeSO}_{4}$ equivalents per gram of fruit $\left(\mu \mathrm{M} \mathrm{FeSO}{ }_{4} \mathrm{E} / \mathrm{g}\right)$. } \\
\hline \multicolumn{7}{|c|}{${ }^{Y}$ percent superoxide radical scavenging activity is given for $10 \mathrm{mg} I D F / \mathrm{ml}$ of the extracts } \\
\hline${ }^{\delta} \mathrm{IC}_{50} \mathrm{va}$ & re expressed & $\mathrm{ng} I \mathrm{ID} / \mathrm{ml}$ & & & & \\
\hline
\end{tabular}

cashew nut, dry dates, ground nut, piyal seeds, walnuts and fig, as reported earlier (Reddy et al., 2010). High level of FRAP activity was found in extracts of less polar combination $(100 \%$ and $80 \%)$ of methanol and DMF and more polar combination ( $80 \%$ and $50 \%$ ) of ethanol and acetone (Table 1). It was least in $100 \%$ 
ethanol, followed by $50 \%$ DMF, and $50 \%$ methanol extract. FRAP results demonstrated that medium polar solvents were suitable for antioxidant recovery. The positive correlation $(r=0.808)$ of FRAP assay with TPC (Table 2) signifies electron donating capacity of phenolic compounds (Reddy et al., 2010).

Oxygen radical antioxidant capacity (ORAC) assay measures the antioxidant capacity at biological pH (7.4) in phosphate buffer saline against biologically relevant synthetic oxidant, AAPH. High ORAC level, ranging from 7.9 to $32.8 \mu \mathrm{M} \mathrm{TE} / \mathrm{g}$ (Table 1) was observed. The observation is in accordance with earlier report (Ammar, del Mar Contreras, Belguith-Hadrich, Bouaziz, \& Segura-Carretero, 2015) in which 7.0 to $40.0 \mu \mathrm{M}$ $T E / g$ ORAC for different varieties of figs was found. An equivalent ORAC value was reported in dry fig and other dry fruits of Indian diet (Reddy et al., 2010). Acetone, ethanol and methanol extracts showed increasing ORAC with increasing proportion of water, but reverse trend was observed for DMF extracts. All the solvent extracts could be arranged in the decreasing order of respective ORAC as: $100 \%$ DMF $>100 \%$ methanol $>80 \%$ DMF $>50 \%$ acetone $>80 \%$ methanol $>50 \%$ ethanol $>80 \%$ ethanol $>80 \%$ acetone $>50 \%$ methanol $>50 \%$ DMF $>100 \%$ ethanol $>100 \%$ acetone. ORAC had a good correlation $(r=0.701)$ with TPC (Table 2), but was comperatively weaker than the correlation of DPPH or ABTS antioxidant capacities with TPC. The reason might be, different HAT based mechanism for ORAC as compared to ABTS or DPPH assay which rely on ET based mechanism.

SRSA ranged from 32 to $68 \%$ for various solvent extracts ( $10 \mathrm{mg} \mathrm{IDF} / \mathrm{ml}$ ) of fig (Table 1$)$. A similar activity was shown in a previous study on fresh plums (Chun, Kim, \& Lee, 2003). SRSA (Table 1) was the highest in $80 \%$ methanol extract and gradually reduced in the order: $50 \%$ acetone $>80 \%$ acetone $>50 \%$ methanol $>$ $100 \%$ DMF $>80 \%$ ethanol $>50 \%$ ethanol $>100 \%$ methanol $>80 \%$ DMF $>100 \%$ ethanol $>50 \%$ DMF $>100 \%$ acetone extracts. The SRSA showed positive correlation with TPC and other antioxidant capacities (Table 2). SRSA result is in agreement with previous report which showed positive correlation between SRSA and TPC determined in Sonchus asper extracts (Khan, Khan, Sahreen, \& Ahmed, 2012). Superoxide anion $\left(\mathrm{O}_{2}^{-}\right)$is a biologically relevant radical which can directly damage cellular macromolecules (Siddhuraju \& Becker, 2003). Therefore, superoxide radical scavenging activity of the fig supports its role in various diseases (Lim, 2012) and antiproliferative activity shown in present study.

\subsection{Correlation studies}

Statistical analysis shows a good correlation (Table 2) between TPC and antioxidant activities as determined by ABTS $(r=0.701)$, DPPH $(r=0.885)$, FRAP $(r=0.808)$, ORAC $(r=0.793)$, and SRSA $(r=0.600)$ assay. Further, antioxidants capacities are well correlated among each other (Table 2). Similar correlations were reported earlier (Ammar et al., 2015; Solomon et al., 2006), which suggest that phenolic compounds might be major antioxidants present in fig extracts. Phenolic compounds have the ability to scavenge free radicals, chelate pro-oxidant metal ions and inhibit enzymes involved in oxidant production. The hydroxyl groups of phenolic compounds can easily transfer hydrogen ion to free radicals producing phenoxide radicals, comparatively stable products (Slatnar et al., 2011). 
Table 2: Correlation among total phenolic content and antioxidant capacity determined by DPPH, ABTS, ORAC, FRAP assay, SRSA and IC ${ }_{50}$

\begin{tabular}{|c|c|c|c|c|c|c|c|c|}
\hline & & TPC & ABTS & DPPH & FRAP & ORAC & $\%$ SRSA & $\mathrm{IC}_{50}$ \\
\hline \multirow[t]{2}{*}{ TPC } & Pearson correlation & 1 & & & & & & \\
\hline & Sig. (2-tailed) & & & & & & & \\
\hline \multirow[t]{2}{*}{ ABTS } & Pearson correlation & 0.885 & 1 & & & & & \\
\hline & Sig. (2-tailed) & 0.000 & & & & & & \\
\hline \multirow[t]{2}{*}{ DPPH } & Pearson correlation & 0.889 & 0.926 & 1 & & & & \\
\hline & Sig. (2-tailed) & 0.000 & 0.000 & & & & & \\
\hline \multirow[t]{2}{*}{ FRAP } & Pearson correlation & 0.808 & 0.865 & 0.927 & 1 & & & \\
\hline & Sig. (2-tailed) & 0.000 & 0.000 & 0.000 & & & & \\
\hline \multirow[t]{2}{*}{ ORAC } & Pearson correlation & 0.701 & 0.888 & 0.817 & 0.697 & 1 & & \\
\hline & Sig. (2-tailed) & 0.011 & 0.000 & 0.001 & 0.011 & & & \\
\hline \multirow[t]{2}{*}{$\%$ SRSA } & Pearson correlation & 0.177 & 0.038 & 0.132 & 0.249 & -0.156 & 1 & \\
\hline & Sig. (2-tailed) & 0.581 & 0.905 & 0.680 & 0.434 & 0.627 & & \\
\hline \multirow[t]{2}{*}{$\mathrm{IC}_{50}$} & Pearson correlation & -0.244 & -0.448 & -0.350 & -0.456 & -0.432 & -0.459 & 1 \\
\hline & Sig. (2-tailed) & 0.443 & 0.143 & 0.264 & 0.135 & 0.210 & 0.133 & \\
\hline
\end{tabular}

\subsection{UPLC analysis of major phenolic compounds}

UPLC-PDA method was applied for analysis of phenolics in fig extracts. Six Phenolic compounds- cyanidin 3-0-glucoside, quercetin 3- $\beta$-glucoside, trans-cinnamic acid, ellagic acid, rutin and ferulic acid were studied (Fig. 2). Retention time and quantities of the

analysed phenolic compounds are shown in Table 3. Positive correlation of individual compounds (Table 3) with TPC was observed, implying the influence of solvent combination on TPC recoveries. Quantities of rutin and cyanidin 3-0-glucoside of fig used in the study was slightly higher than previously reported fig varieties from Italy, Greece and Turkey on extraction in $80 \%$ aqueous-methanol (Russo, Caporaso, Paduano, \& Sacchi, 2014).

Table 3. Quantities of cyanidin 3-0-glucoside, quercetin 3- $\beta$-D-glucoside, trans-cinnamic acid, ellagic acid, rutin, and ferulic acid determined by UPLC-PDA analysis in various solvent extract of dried fig and their correlation with TPC and $\mathrm{IC}_{50}$ values. 


\begin{tabular}{|c|c|c|c|c|c|c|c|}
\hline Solvent & $\begin{array}{l}\text { ¿Cyanidin } \\
3-0- \\
\text { glucoside }\end{array}$ & $\begin{array}{l}\varepsilon \text { Quercetin 3- } \\
\text { B-D- } \\
\text { glucoside }\end{array}$ & $\begin{array}{l}{ }^{\varepsilon} \text { Trans- } \\
\text { cinnamic } \\
\text { acid }\end{array}$ & $\begin{array}{l}\varepsilon \text { Ellagic } \\
\text { acid }\end{array}$ & ${ }^{\varepsilon}$ Rutin & $\begin{array}{l}{ }^{\varepsilon} \text { Ferulic } \\
\text { acid }\end{array}$ & $\Sigma^{\varepsilon \pi}$ \\
\hline $\mathrm{X}_{\mathrm{RT}}$ & 3.99 & 4.55 & 5.28 & 3.6 & 3.44 & 3.94 & \\
\hline \multicolumn{8}{|l|}{ Acetone } \\
\hline $100 \%$ & $11.8 \pm 0.3$ & $3.9 \pm 0.4^{\mathrm{ce}}$ & $8 \pm 0.05^{a}$ & $17.3 \pm 0.4^{a}$ & $41.4 \pm 0.5^{d}$ & $7.1 \pm 0.1^{c}$ & 82.5 \\
\hline $80 \%$ & $36.8 \pm 0.7$ & $9.4 \pm 0.4^{a}$ & $3.8 \pm 0.2^{a}$ & $31 \pm 0.5^{\mathrm{bd}}$ & $39.1 \pm 0.5^{d}$ & $16.7 \pm 0.6^{\mathrm{a}}$ & 136.9 \\
\hline $50 \%$ & $53 \pm 0.8^{c}$ & $23.8 \pm 0.3^{c e}$ & $4.9 \pm 0.1^{\mathrm{a}}$ & $34.6 \pm 0.1^{b}$ & $94.3 \pm 1.5^{c}$ & $36.6 \pm 0.4^{d}$ & 247.4 \\
\hline \multicolumn{8}{|l|}{ Ethanol } \\
\hline $100 \%$ & $15.9 \pm 0.3^{c}$ & $5.3 \pm 0.2^{\text {ace }}$ & $0.8 \pm 0.1^{a}$ & $20.5 \pm 0.8^{\mathrm{ad}}$ & $48.7 \pm 0.3$ & $8.1 \pm 0.2^{c}$ & 99.6 \\
\hline $80 \%$ & $69.1 \pm 0.9^{\mathrm{ed}}$ & $14.4 \pm 0.2^{\text {af }}$ & $5.4 \pm 0.1^{\mathrm{a}}$ & $49.3 \pm 0.7^{c}$ & $59 \pm 0.4^{a}$ & $32.3 \pm 0.7^{d}$ & 229.8 \\
\hline $50 \%$ & $73 \pm 0.2^{\text {ad }}$ & $17.1 \pm 0.6^{\mathrm{cdf}}$ & $6.5 \pm 0.2^{a}$ & $53.3 \pm 0.4 b^{c}$ & $64.4 \pm 0.5^{\mathrm{a}}$ & $42.3 \pm 0.5^{d}$ & 256.8 \\
\hline \multicolumn{8}{|c|}{ Methanol } \\
\hline $100 \%$ & $66.2 \pm 2.9^{a}$ & $10.7 \pm 0.5^{\mathrm{a}}$ & $3.3 \pm 0.2^{\mathrm{a}}$ & $21.3 \pm 1^{a}$ & $61.3 \pm 9^{a}$ & $21.5 \pm 1.2^{a}$ & 184.6 \\
\hline $80 \%$ & $78.3 \pm 1.5^{\mathrm{b}}$ & $37.8 \pm 0.8^{b}$ & $13.9 \pm 0.1$ & $29 \pm 0.8^{b}$ & $84 \pm 0.5^{b}$ & $24.5 \pm 0.8^{a}$ & .8 \\
\hline $50 \%$ & $54.4 \pm 0.8^{c}$ & $10.6 \pm 0.4^{\mathrm{ac}}$ & $3.2 \pm 0.3^{\mathrm{a}}$ & $21.4 \pm 0.3^{\mathrm{a}}$ & $61.4 \pm 0.8^{\mathrm{a}}$ & $19.1 \pm 1.2^{\mathrm{a}}$ & 170.4 \\
\hline \multicolumn{8}{|l|}{ DMF } \\
\hline $100 \%$ & $71.8 \pm 0.7^{\text {ad }}$ & $42 . \pm 0.6^{b}$ & $5.7 \pm 0.7^{a}$ & $51.8 \pm 0.8^{c}$ & $97.3 \pm 1^{c}$ & $57.6 \pm 0.4$ & 326.5 \\
\hline $80 \%$ & $64.7 \pm 1.2^{\mathrm{ae}}$ & $10.8 \pm 0.3^{\mathrm{ad}}$ & $4.4 \pm 0.1^{\mathrm{a}}$ & $22.5 \pm 0.9^{\text {ad }}$ & $79.9 \pm 0.2^{b}$ & $20.2 \pm 0.3^{\mathrm{a}}$ & 202.7 \\
\hline $50 \%$ & $54.2 \pm 1.7^{\mathrm{bc}}$ & $10.1 \pm 1.2^{\mathrm{a}}$ & $4.1 \pm 0.4^{\mathrm{a}}$ & $22 \pm 0.7^{\text {af }}$ & $63.6 \pm 1^{a}$ & $18.8 \pm 1.2^{\mathrm{a}}$ & 173 \\
\hline$\psi_{\mathrm{r}}$ TPC & 0.73 & 0.66 & 0.64 & 0.36 & 0.78 & 0.61 & 0.76 \\
\hline $\mathbf{P}$ & 0.0062 & 0.0192 & 0.0236 & 0.2544 & 0.0025 & 0.0349 & 0.0036 \\
\hline$\lambda_{\mathrm{r}} \mathrm{IC}_{50}$ & -0.74 & -0.60 & -0.60 & -0.47 & -0.59 & -0.57 & -0.72 \\
\hline $\mathbf{P}$ & 0.0056 & 0.0384 & 0.0391 & 0.1191 & 0.0399 & 0.0522 & 0.0082 \\
\hline \multicolumn{8}{|c|}{$\begin{array}{l}\text { Note: } \mathrm{XRT}_{\mathrm{RT}}=\text { Retention time in minutes; }{ }^{\varepsilon} \text { values are presented as mean } \pm \mathrm{SEM}(\mathrm{n}=3) \mathrm{mg} / 100 \mathrm{~g} \text { dry fruit; } \\
{ }^{\pi} \text { sum of all quantified phenolics; } \\
{ }^{\psi} \text { Pearson correlation coefficient between quantity of given phenolic compound and TPC (Figure 1) at } \\
\text { respective significance level; } P \text { is less than given value }\end{array}$} \\
\hline
\end{tabular}


${ }^{\lambda}$ Pearson correlation coefficient between given phenolic compound and corresponding $\mathrm{IC}_{50}$ at respective significance level - $\mathrm{P}$ is less than given value

Recoveries of ellagic acid, quercetin 3- $\beta$-glucoside, rutin and cyanidin 3-0-glucoside were more when compared to (Table 3) previous report on fig fruit extracted in $75 \%$ aqueous-methanol (Kamiloglu \& Capanoglu, 2014) or hot water (Oliveira et al., 2009).

\subsection{Antiproliferative activity}

Antiproliferative activity of different fig solvent extracts were tested against triple negative breast cancer cells; MDA MB-468. An observable decrease in cell viabilities after $24 \mathrm{hr}$ of treatment with each extract in a dose-dependent manner occured (Fig. 3). IC 50 were 80.4, 41.2, 36.4, 43.31, 38.19, 30.37, 36.79, 17.97, 38.35, $22.0,30.1,62.3 \mathrm{mg} \mathrm{IDF} / \mathrm{ml}$ for $100 \%, 80 \%, 50 \%$ of acetone, ethanol, methanol, and DMF extracts of the fig respectively (Table 1). IC $\mathrm{I}_{50}$ values of dry residue was $3.93,6.47,5.87,1.93,5.72,4.61,6.04,3.03,5.76,4.01$, 5.05 , and $9.99 \mu \mathrm{g} / \mathrm{ml}$ for aforementioned extracts respectively. Minimum effective dose (minimum dose causing significant decrease in cell viability as compared to control) were $30(P<0.01), 10(P<0.05), 5(P<$ 0.05), 30 ( $P<0.01), 10$ ( $P<0.001), 10$ ( $P<0.05), 10$ ( $P<0.001), 10(P<0.01), 50 \mathrm{mg} \mathrm{IDF} / \mathrm{ml}(P<0.01)$ for $100 \%, 80 \%, 50 \%$ of ethanol, methanol and DMF extracts sequentially. It was $30(P<0.05)$ and $30 \mathrm{mg} I D F / \mathrm{ml}$ $(P<0.01)$ for $80 \%$ and $50 \%$ for acetone extract respectively. However, there was no significant decrease in cell viability in case of $100 \%$ acetone extract (Fig. 3).

Increasing percentage of water in methanol, ethanol, and acetone enhanced cytotoxic property, but for DMF the trend was reversed. Methanol $80 \%$ extract was the most effective with $I_{50}$ value of $17.97 \mathrm{mg} \mathrm{IDF} / \mathrm{ml}$. Results suggest that extracts of modest polar solvents had better antiproliferative activity. TPC and antioxidant capacity of the extracts might be contributing towards antiproliferative property. A fair negative correlation between $\mathrm{IC}_{50}$, respective TPC and antioxidant capacities was found (Table 2). Previous report on Theobroma cacao also exhibited similar correlation (Baharum, Akim, Taufiq-Yap, Hamid, \& Kasran, 2014).

$\mathrm{IC}_{50}$ ranged from 1.93 to $9.99 \mu \mathrm{g} / \mathrm{ml}$. Results of the present stduy showed a better antiproliferative activity than previous report on MDA MB-468 cells (Ayob, Mohd Bohari, Abd Samad, \& Jamil, 2014). A similar study by Baharum et al. (2014) on MDA MB-231 reported that methanolic exctract of Theobroma cacao has comparatively low antiproliferatve activity. In addition, fig also has lower $\mathrm{IC}_{50}$ than several vegetables, namely cucumber, lettuce, celery, onion, cabbage, spinach, carrot, broccoli, red pepper (Chu et al., 2002).

\subsection{Cell death analysis by flow cytometry}

Fragmentation of nuclear DNA is an integral part of cell death process leading to hypodiploid condition. Propeidium iodied staining followed by flow-cytometry-scoring of treated cells was done to enable quantification of hypodiploid dead, and diploid live cell population (Fig. 4.a). Various solvent extracts induced cell death in dose dependent manner in MDA MB-468 cells; higher dose (40 mg IDF/ml) was more effective than lower dose $(20 \mathrm{mg} I D F / \mathrm{ml})$. All extracts induced cell death significantly $(P<0.05)$ at 40 
$\mathrm{mgIDF} / \mathrm{ml}$ treatment concentration as compared to control (Fig. 4.b). However, at same dose very very significant $(P<0.001)$ cell death took place as compared to control when absolute methanol, $80 \%$ methanol or $50 \%$ acetone extracts were applied (Fig. 4.b). At lower dose (20 mg IDF/ml) $100 \%, 80 \%$, and 50\% methanol, $100 \%$ DMF and $50 \%$ acetone extract triggered cell death significantly $(P<0.05)$ as compared to control. Among all, $80 \%$ methanol extract was most effective which induced death in $43 \pm 4.5$ and $64 \pm 6.4 \%$ cells at 20 and $40 \mathrm{mg} \mathrm{IDF/ml} \mathrm{doses} \mathrm{respectively} \mathrm{(Fig.} \mathrm{4.b).} \mathrm{The} \mathrm{observation} \mathrm{was} \mathrm{in} \mathrm{line} \mathrm{with} \mathrm{previous} \mathrm{work}$ reporting cell death in HeLa cells treated with Oroxylum indicum bark extracts (Moirangthem, Talukdar, Bora, Kasoju, \& Das, 2013). Score of percent dead cells was positively correlated with TPC $(r=0.32$ and 0.67 for 20 and $40 \mathrm{mg} \mathrm{IDF} / \mathrm{ml}$ doses respectively) and negatively correlated with $\mathrm{IC}_{50}(r=-0.57$ and -0.61 for 20 and $40 \mathrm{mg} \mathrm{IDF} / \mathrm{ml}$ doses respectively). Present finding is in accordance with reports on other plants which showed efficacy of polyphenol rich extract against cancer cell proliferation (Cai, Luo, Sun, \& Corke, 2004).

$\mathrm{IC}_{50}$ was negatively correlated and cell death was positively correlated with each of the analysed phenolic compounds (Table 3). It suggests that phenolic compounds i.e. trans-cinnamic acid, ferulic acid, ellagic acid, cyanidin 3-0-glucoside, quercetin 3- $\beta$-glucoside might be accounting for antiproliferative property (Table 3).

Antiproliferative activity of dry fig is supported by its anti-inflammatory property as it alleviates an elevated plasma cytokine (inteleukins: IL-2, IL-3, IL-4, IL-5, IL-9, IL-10; and Eotaxin) level by 22.27 to $30.49 \%$ in transgenic mice (Essa, Subash, Akbar, Al-Adawi, \& Guillemin, 2015). Fig is reported to significantly increase blood plasma antioxidant capacity, and inhibit low-density lipoproteins oxidation in human (Vinson, Zubik, Bose, Samman, \& Proch, 2005). Therefore, results of present study suggest fig as anticancer diet; moderately polar solvents ( $50 \%$ acetone, $50 \%$ ethanol, $80 \%$ methanol and absolute DMF) showed better antiproliferative activity. The antiproliferative activity is supported by respective antioxidant capacity and phenolics composition of the extracts.

\section{Conclusion}

Fig extracts in moderately polar solvents (50\% acetone, $50 \%$ ethanol, $80 \%$ methanol and absolute DMF) exhibited high TPC, antioxidant capacity and antiproliferative activity against breast cancer (MDA MB-468) cells. Methanol $80 \%$ extract showed maximum antiproliferative activity $\left(I C_{50}=17.97\right)$. Moreover, extracts with high TPC and low $\mathrm{IC}_{50}$ induced more cell death. Negative correlation of TPC, antioxidant capaciy and quantities of analysed phenolics (cyanidin 3-0-glucoside, quercetin, trans-cinnamic acid, ellagic acid, rutin and ferulic acid) with $\mathrm{IC}_{50}$ suggests direct role of phenolics in antiproliferative mechanism of fig.

\section{Abbreviations}

AAPH, 2,2'-azobis(2-methylpropionamidine) dihydrochloride; ABTS, 2,2'-azino-bis(3- ethylbenzothiazoline-6sulfonic acid) diammonium salt; ANOVA, analysis of variance; AUC, area under curve; DMEM, Dulbecco's modified eagle medium; DMF, N, N-dimethylformamide; DMSO, dimethyl sulfoxide; SEM, standard error of mean; DNA, deoxyribose nucleic acid; DNase, deoxyribonuclease; DPPH, 2,2-diphenyl-1-picrylhydrazyl; ET, electron transfer; FRAP, ferric reducing antioxidant capacity; GAE, gallic acid equivalent; HAT, hydrogen atom 
transfer; $\mathrm{IC}_{50}$, median inhibitory concentration; IDF/ml, Infusion from per unit weight of dry fig per $\mathrm{ml}$; IL, inteleukins; MTT, (3-(4,5-dimethylthiazol-2-yl)-2,5-diphenyltetrazolium bromide; NBT, nitrotetrazolium blue chloride; ORAC, oxygen radical antioxidant capacity; PBS, phosphate buffer saline; RNase-A, an endoribonuclease that specifically degrades single-stranded RNA at $C$ and $U$ residues; ROS, reactive oxygen species; SRSA, superoxide radical scavanging activity; TAOC, total antioxidant capacity; TE, trolox equivalent; TFA, trifluoroacetic acid; TPC, total phenolic content; TPTZ, 2,4,6-tri(2-pyridyl)-s-triazine; BEH, ethylene bridged hybrid, UPLC-PDA, ultra performance liquid chromatography-photodiode array detector

\section{Declarations}

Chemical compounds: Cyanidin 3-0-glucoside (PubChem CID: 12303203); Rutin (PubChem CID: 5280805); Quercetin-3- $\beta$-D-glucoside (PubChem CID: 25203368); trans-cinnamic acid (PubChem CID: 444539); ferulic acid (PubChem CID: 445858); ellagic acid (PubChem CID: 5281855)

Competing Interest: The authours declare no conflict of interest.

Ethical approval: The article does not have any studies conducted on human participants or animals.

Acknowledgements: Author acknowledges Indian Council of Medical Research, India for research fellowship grant, Central Instrumentation Facility, Biotech Centre, University of Delhi South Campus, Delhi for UPLC analyses and National Centre for Cell Sciences, Pune for providing cell line. Financial assistance received from UPE-II and DST-PURSE are grateatfully acknowleged.

\section{References}

1. Ammar, S., Contreras, M. del M., Belguith-Hadrich, O., Bouaziz, M., \& Segura-Carretero, A. (2015). New insights into the qualitative phenolic profile of Ficus carica L. fruits and leaves from Tunisia using ultrahigh-performance liquid chromatography coupled to quadrupole-time-of-flight mass spectrometry and their antioxidant activity. RSC Adv., 5(26), 20035-20050. https://doi.org/10.1039/C4RA16746E

2. Asiaf, A., Ahmad, S. T., Malik, A. A., \& Aziz, S. A. (2015). Protein expression and methylation of MGMT , a DNA repair gene and their correlation with clinicopathological parameters in invasive ductal carcinoma of the breast. Tumor Biology, 36(8), 6485-6496. https://doi.org/10.1007/s13277-015-3339-9

3. Ayob, Z., Mohd Bohari, S. P., Abd Samad, A., \& Jamil, S. (2014). Cytotoxic activities against breast cancer cells of local Justicia gendarussa crude extracts. Evidence-Based Complementary and Alternative Medicine, 2014. https://doi.org/10.1155/2014/732980

4. Bachir Bey, M., Meziant, L., Benchikh, Y., \& Louaileche, H. (2014). Deployment of response surface methodology to optimize recovery of dark fresh fig (Ficus carica L., var. Azenjar) total phenolic compounds and antioxidant activity. Food Chemistry. https://doi.org/10.1016/j.foodchem.2014.04.054

5. Baharum, Z., Akim, A. M., Taufiq-Yap, Y. H., Hamid, R. A., \& Kasran, R. (2014). In Vitro Antioxidant and Antiproliferative Activities of Methanolic Plant Part Extracts of Theobroma cacao. Molecules. https://doi.org/10.3390/molecules191118317 
6. Barolo, M. I., Ruiz Mostacero, N., \& López, S. N. (2014). Ficus carica L. (Moraceae): An ancient source of food and health. Food Chemistry. https://doi.org/10.1016/j.foodchem.2014.04.112

7. Boeing, J. S., Barizão, É. O., e Silva, B. C., Montanher, P. F., de Cinque Almeida, V., Visentainer, J. V., ... Burini, G. (2014). Evaluation of solvent effect on the extraction of phenolic compounds and antioxidant capacities from the berries: application of principal component analysis. Chemistry Central Journal, 8(1), 48. https://doi.org/10.1186/s13065-014-0048-1

8. Cai, Y., Luo, Q., Sun, M., \& Corke, H. (2004). Antioxidant activity and phenolic compounds of 112 traditional Chinese medicinal plants associated with anticancer. Life sciences, 74(17), 2157-2184.

9. Chu, Y. F., Sun, J., Wu, X., \& Liu, R. H. (2002). Antioxidant and antiproliferative activities of common vegetables. Journal of Agricultural and Food Chemistry, 50(23), 6910-6916.

https://doi.org/10.1021/jf020665f

10. Do, Q. D., Angkawijaya, A. E., Tran-Nguyen, P. L., Huynh, L. H., Soetaredjo, F. E., Ismadji, S., \& Ju, Y. H. (2014). Effect of extraction solvent on total phenol content, total flavonoid content, and antioxidant activity of Limnophila aromatica. Journal of Food and Drug Analysis, 22(3), 296-302.

https://doi.org/10.1016/j.jfda.2013.11.001

11. Essa, M. M., Subash, S., Akbar, M., Al-Adawi, S., \& Guillemin, G. J. (2015). Long-Term dietary supplementation of pomegranates, figs and dates alleviate neuroinflammation in a transgenic mouse model of alzheimer's disease. PLOS ONE. https://doi.org/10.1371/journal.pone.0120964

12. Farvid, M. S., Chen, W. Y., Michels, K. B., Cho, E., Willett, W. C., \& Eliassen, A. H. (2016). Fruit and vegetable consumption in adolescence and early adulthood and risk of breast cancer: population based cohort study. BMJ: British Medical Journal, 353(i2343), 1-12. https://doi.org/10.1136/bmj.i2343

13. Gawade, M. H., \& Waskar, D. P. (2005). Effect of different varieties and pretreatments on yield and qualify of dried fig fruits. Indian Journal of Agricultural Research, 39(2), 138-141.

14. Ginsburg, O., Bray, F., Coleman, M. P., Vanderpuye, V., Eniu, A., Kotha, S. R., ... Conteh, L. (2017). The global burden of women's cancers: a grand challenge in global health. The Lancet, 389(10071), 847860. https://doi.org/10.1016/S0140-6736(16)31392-7

15. Govindan, P., \& Muthukrishnan, S. (2013). Evaluation of total phenolic content and free radical scavenging activity of Boerhavia erecta. Journal of Acute Medicine, 3(3), 103-109. https://doi.org/10.1016/j.jacme.2013.06.003

16. Kamiloglu, S., \& Capanoglu, E. (2014). Polyphenol Content in Figs (Ficus carica L.): Effect of SunDrying. International Journal of Food Properties, 18(3), 521-535.

https://doi.org/10.1080/10942912.2013.833522

17. Khan, R. A., Khan, M. R., Sahreen, S., \& Ahmed, M. (2012). Evaluation of phenolic contents and antioxidant activity of various solvent extracts of Sonchus asper (L.) Hill. Chemistry Central Journal, 6(1), 12. https://doi.org/10.1186/1752-153X-6-12

18. Kim, D. O., \& Lee, C. Y. (2005). Extraction And Isolation Of Polyphenolics. In Handbook of Food Analytical Chemistry. https://doi.org/10.1002/0471709085.ch28

19. Kumar, P., Meena, R., Paulraj, R., Chanchal, A., Verma, A. K., \& Bohidar, H. B. (2012). Fluorescence behavior of non-functionalized carbon nanoparticles and their in vitro applications in imaging and 
cytotoxic analysis of cancer cells. Colloids and Surfaces B: Biointerfaces. https://doi.org/10.1016/j.colsurfb.2011.10.034

20. Li, T., Zhu, J., Guo, L., Shi, X., Liu, Y., \& Yang, X. (2013). Differential effects of polyphenols-enriched extracts from hawthorn fruit peels and fleshes on cell cycle and apoptosis in human MCF-7 breast carcinoma cells. Food Chemistry, 141(2), 1008-1018. https://doi.org/10.1016/j.foodchem.2013.04.050 21. Lim, T. K. (2012). Ficus carica. In Edible Medicinal And Non Medicinal Plants (pp. 362-376). Dordrecht: Springer Netherlands. https://doi.org/10.1007/978-94-007-2534-8_51

22. Moirangthem, D. S., Talukdar, N. C., Bora, U., Kasoju, N., \& Das, R. K. (2013). Differential effects of Oroxylum indicum bark extracts: Antioxidant, antimicrobial, cytotoxic and apoptotic study. Cytotechnology, 65(1), 83-95. https://doi.org/10.1007/s10616-012-9463-0

23. Ock Kyoung Chun, Dae-Ok Kim, and, \& Lee*, C. Y. (2003). Superoxide Radical Scavenging Activity of the Major Polyphenols in Fresh Plums. https://doi.org/10.1021/JF034740D

24. Oliveira, A. P., Valentão, P., Pereira, J. a., Silva, B. M., Tavares, F., \& Andrade, P. B. (2009). Ficus carica L.: Metabolic and biological screening. Food and Chemical Toxicology, 47(11), 2841-2846. https://doi.org/10.1016/j.fct.2009.09.004

25. Prior, R. L., Wu, X., \& Schaich, K. (2005). Standarized Methods for the Determination of Antioxidant Capacity and Phenolics in Foods and Dietary Supplements. Journal of Agricultural and Food Chemistry, 53(10), 4290-4302. https://doi.org/10.1021/jf0502698

26. Riccardi, C., \& Nicoletti, I. (2006). Analysis of apoptosis by propidium iodide staining and flow cytometry. Nature Protocols, 1(3), 1458-1461. https://doi.org/10.1038/nprot.2006.238

27. Russo, F., Caporaso, N., Paduano, A., \& Sacchi, R. (2014). Phenolic Compounds in Fresh and Dried Figs from Cilento (Italy), by Considering Breba Crop and Full Crop, in Comparison to Turkish and Greek Dried Figs. Journal of Food Science, 79(7), C1279-C1284. https://doi.org/10.1111/1750-3841.12505

28. Russo, G. L. (2007). Ins and outs of dietary phytochemicals in cancer chemoprevention. Biochemical Pharmacology, 74(4), 533-544. https://doi.org/10.1016/j.bcp.2007.02.014

29. Siddhuraju, P., \& Becker, K. (2003). Antioxidant properties of various solvent extracts of total phenolic constituents from three different agroclimatic origins of drumstick tree (Moringa oleifera Lam.) leaves. Journal of Agricultural and Food Chemistry, 51(8), 2144-2155. https://doi.org/10.1021/jf020444+

30. Slatnar, A., Klancar, U., Stampar, F., \& Veberic, R. (2011). Effect of drying of figs (Ficus carica L.) on the contents of sugars, organic acids, and phenolic compounds. Journal of Agricultural and Food Chemistry, 59(21), 11696-11702. https://doi.org/10.1021/jf202707y

31. Solomon, A., Golubowicz, S., Yablowicz, Z., Grossman, S., Bergman, M., Gottlieb, H. E., ... Flaishman, M. a. (2006). Antioxidant activities and anthocyanin content of fresh fruits of common fig (Ficus carica L.). Journal of Agricultural and Food Chemistry, 54(20), 7717-7723. https://doi.org/10.1021/jf060497h

32. Sun, J., Chu, Y. F., Wu, X., \& Liu, R. H. (2002). Antioxidant and antiproliferative activities of common fruits. Journal of Agricultural and Food Chemistry, 50(25), 7449-7454.

https://doi.org/10.1021/jf0207530 
33. Thaipong, K., Boonprakob, U., Crosby, K., Cisneros-Zevallos, L., \& Hawkins Byrne, D. (2006). Comparison of ABTS, DPPH, FRAP, and ORAC assays for estimating antioxidant activity from guava fruit extracts. Journal of Food Composition and Analysis, 19(6-7), 669-675.

https://doi.org/10.1016/j.jfca.2006.01.003

34. Turkmen, N., Sari, F., \& Velioglu, Y. S. (2006). Effects of extraction solvents on concentration and antioxidant activity of black and black mate tea polyphenols determined by ferrous tartrate and FolinCiocalteu methods. Food Chemistry, 99(4), 835-841. https://doi.org/10.1016/j.foodchem.2005.08.034

35. Vijaya Kumar Reddy, C., Sreeramulu, D., \& Raghunath, M. (2010). Antioxidant activity of fresh and dry fruits commonly consumed in India. Food Research International, 43(1), 285-288. https://doi.org/10.1016/j.foodres.2009.10.006

36. Vinson, J. a, Zubik, L., Bose, P., Samman, N., \& Proch, J. (2005). Dried fruits: excellent in vitro and in vivo antioxidants. Journal of the American College of Nutrition, 24(1), 44-50. https://doi.org/10.1080/07315724.2005.10719442

\section{Figures}

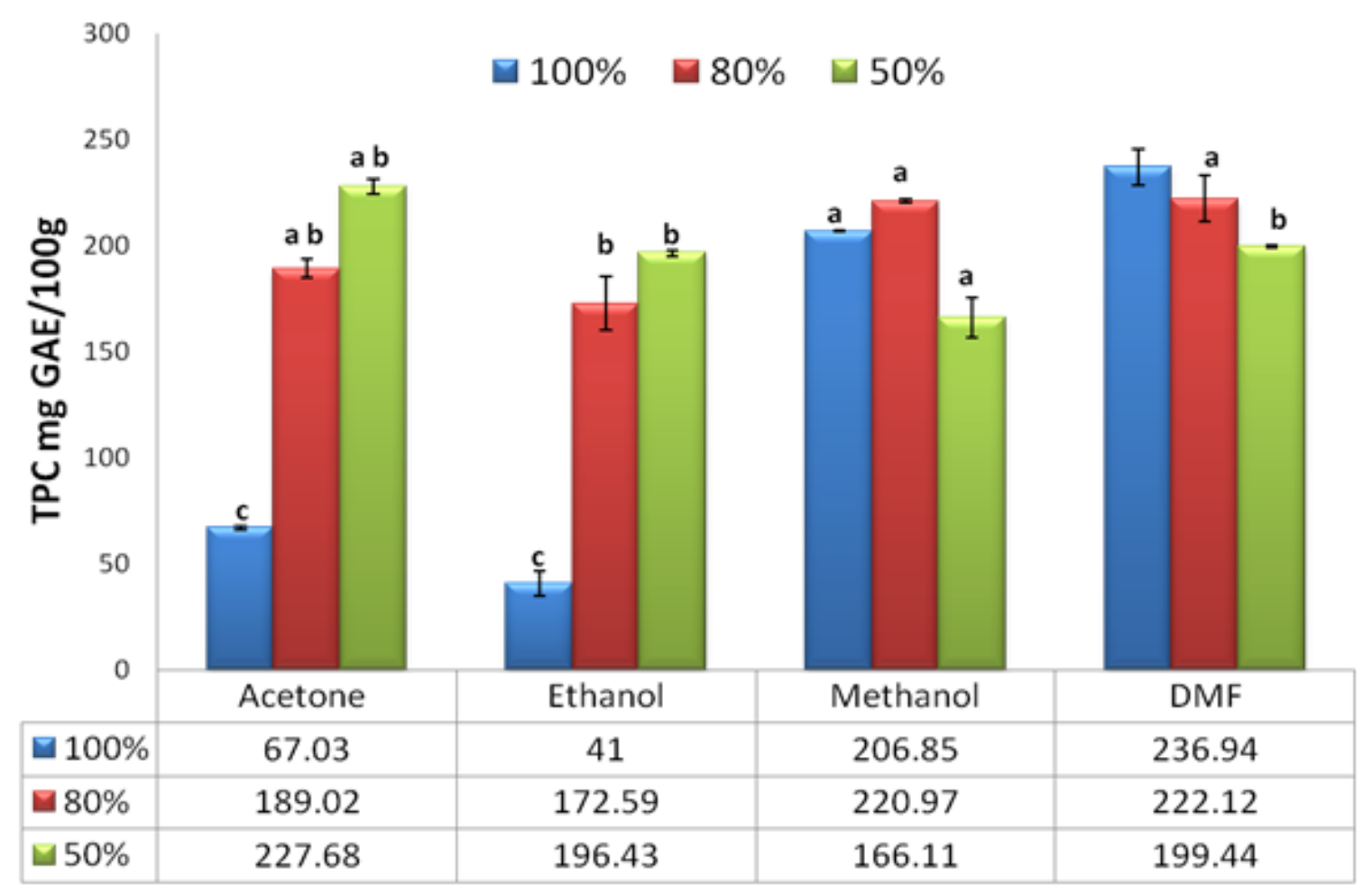

\section{Figure 1}

Total phenolic content (TPC) of dry fig extracted in different solvents.Values are expressed as milligram of gallic acid equivalents per 100 gram (mg GAE/100g) of fruit. Bars represent mean \pm SEM $(n=9)$ value; bars with different letters $(a, b)$ are significantly different from each other $(P<0.05)$. Mean values are given in adjacent table. 

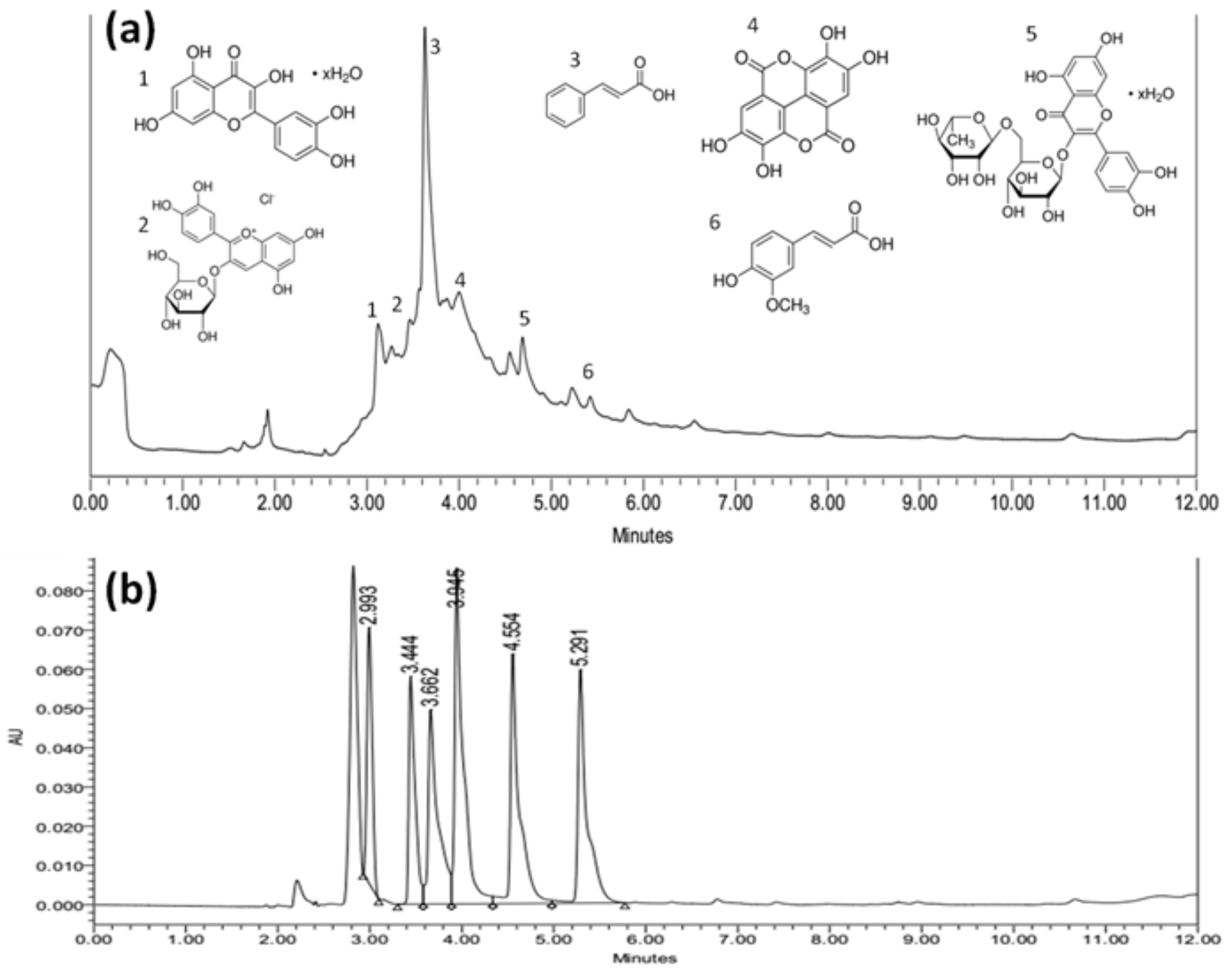

Figure 2

UPLC-PDA analysis of major phenolic compounds.Representative chromatogram of standard mix (a) and sample (b) showing retention time, peaks and structure of cyanidin 3-0-glucoside (1), rutin (2), ellagic acid (3), ferulic acid (4), quercetin 3- $\beta$-D-glucoside (5), and trans-cinnamic acid (6). 


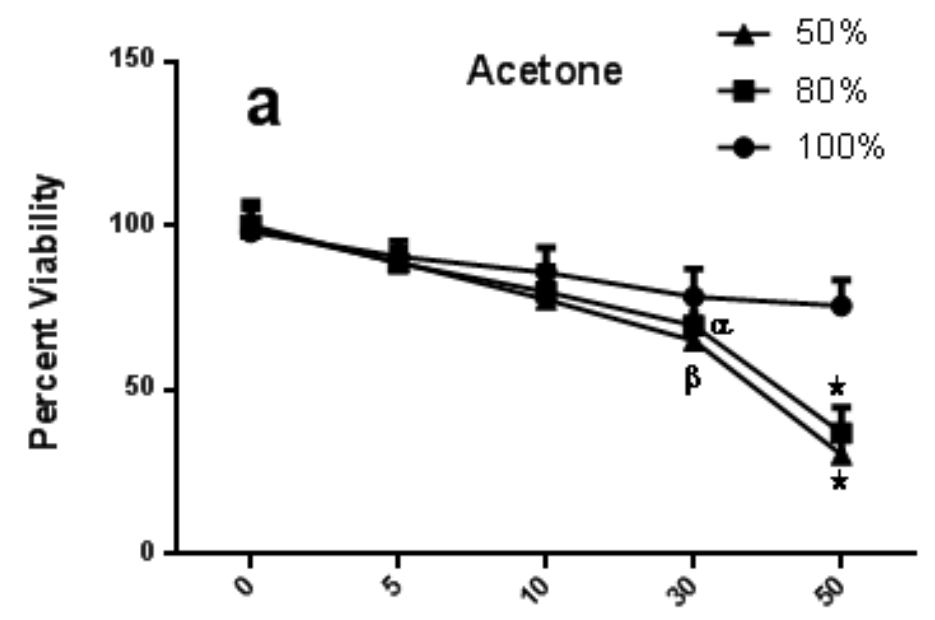

Concentration of extract (m gIDF/mI)

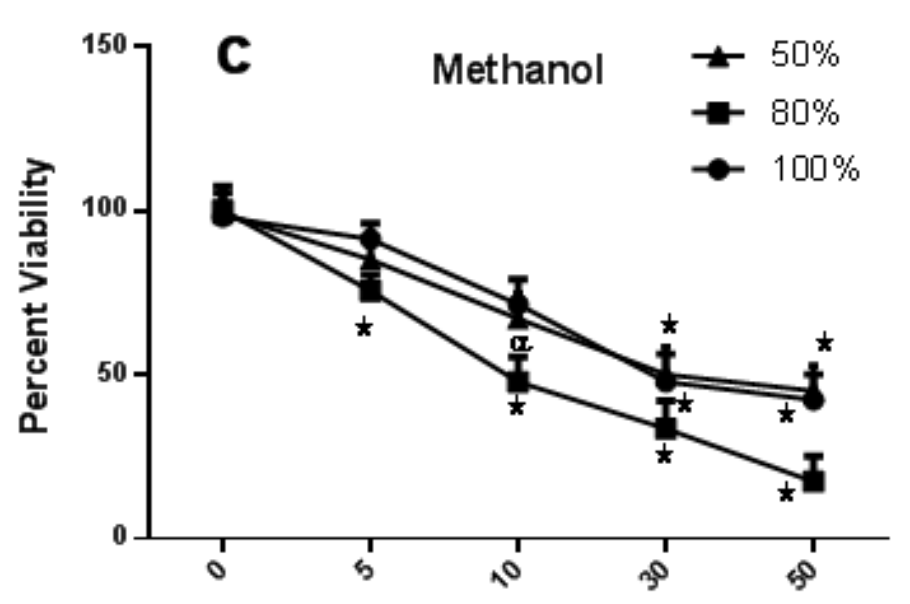

Concentration of extract ( $\mathrm{mgIDF} / \mathrm{ml}$ )
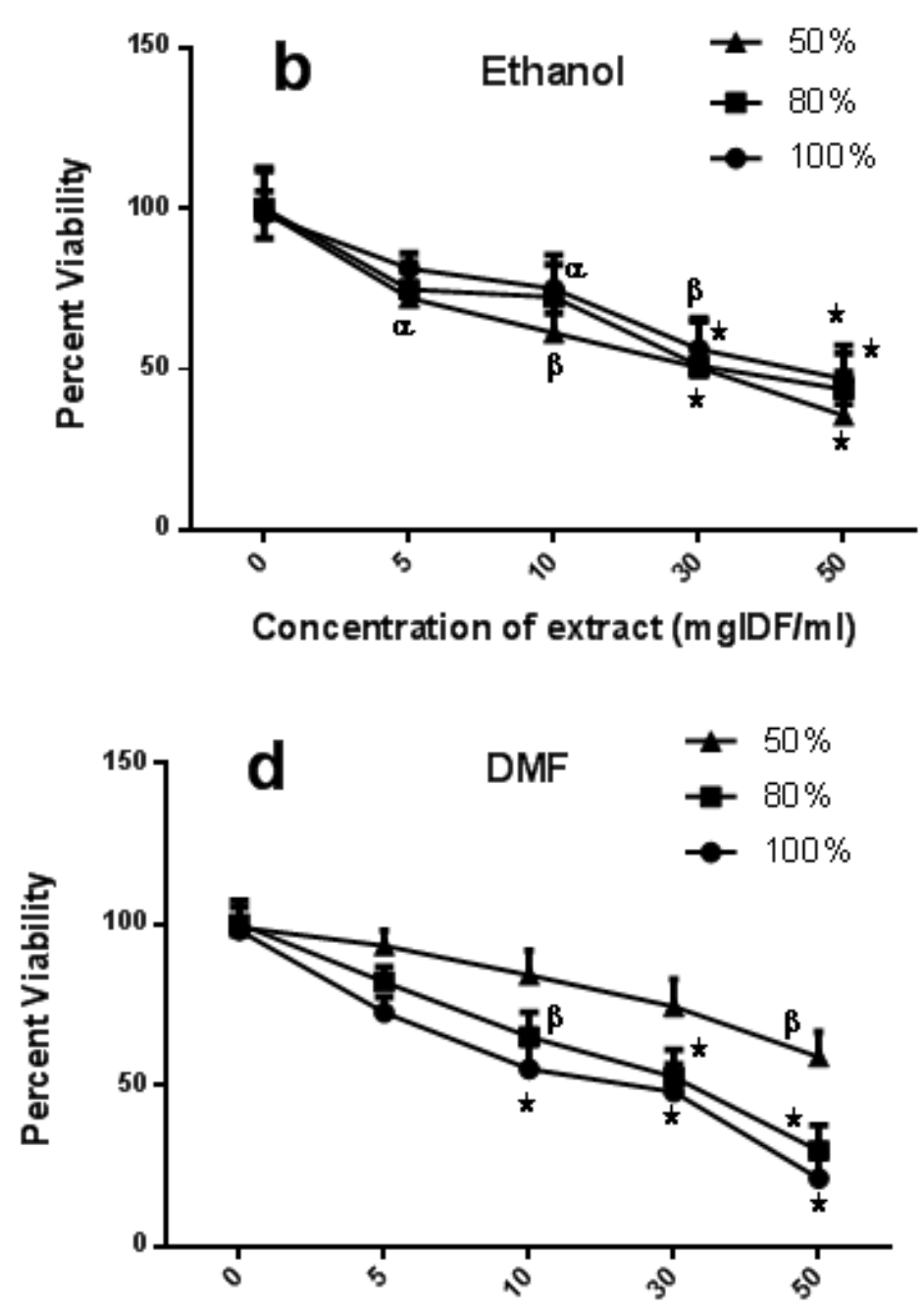

Concentration of extract (mglDF/ml)

Figure 3

Antiproliferative activity of various solvent extracts of dry fig. Dose dependent decrease $\left({ }^{a} P<0.05,{ }^{\beta} P<0.01\right.$, $\left.{ }^{*} \mathrm{P}<0.001\right)$ in proliferation of MDA MB-468 cells treated with aqueous combination $(100 \%, 80 \%, 50 \%)$ of a) acetone, b) ethanol, c) methanol and d) N, N'-dimethylformamide (DMF) extracts; values are given as mean $\pm \operatorname{SEM}(n=3)$. 

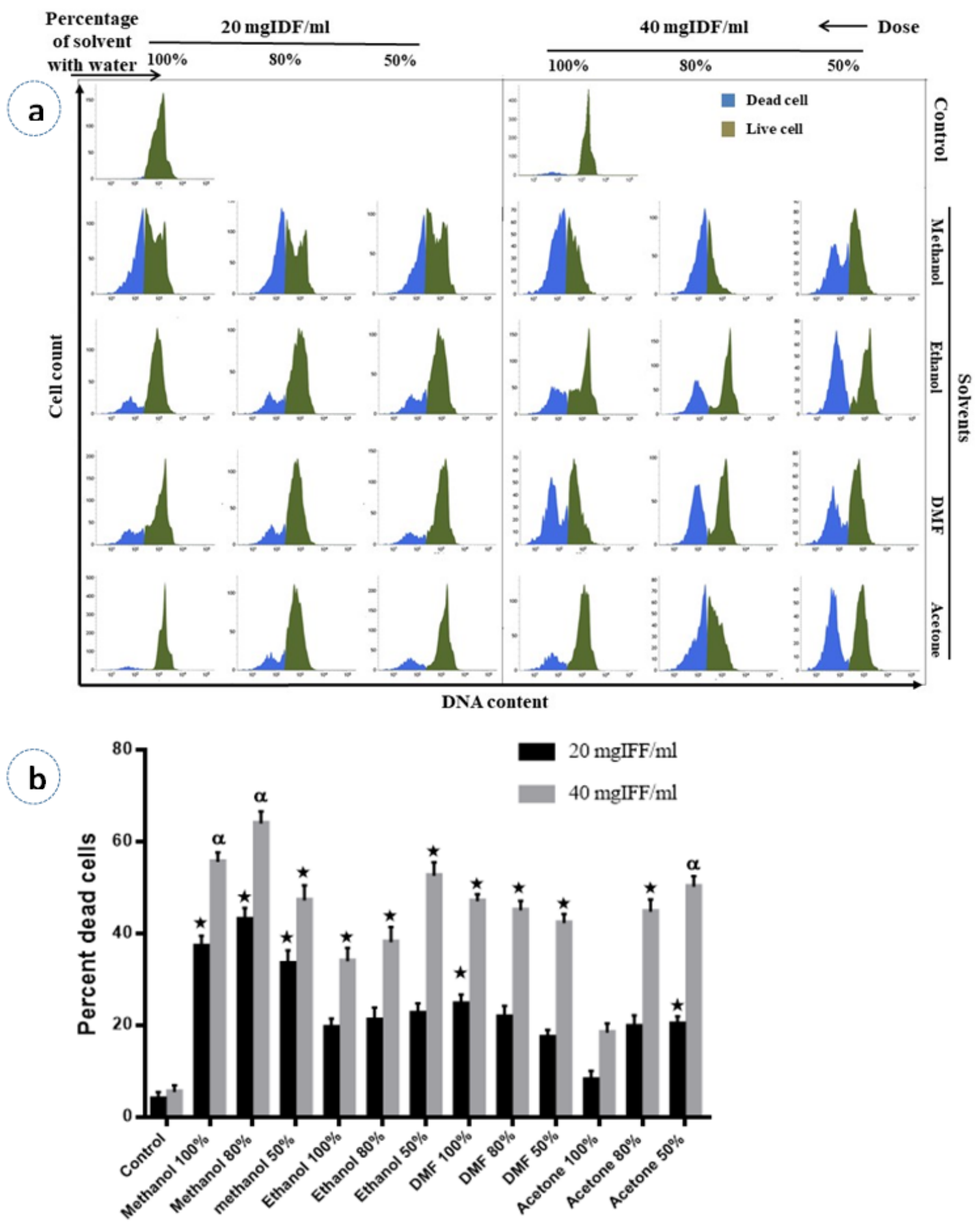

Extraction Solvents

Figure 4

Cell death in MDA MA-468 cells treated with various solvent extracts of dry figs. Flow cytometry histograms (a) demonstrating a significant ( $\left.{ }^{a} P<0.05,{ }^{*} P<0.001\right)$ increase in percent dead cells $(b)$ in MDA MB-468 cells treated with various solvent extracts of fig. Values are given as mean $\pm S D(n=3)$ 